НАУКОВИЙ ВІСНИК

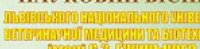

Ventinc messenger of Lviv

Veterinascry Meedicine and Bitionalechnologiesics

.

TIIIT

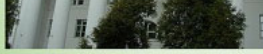

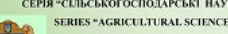

Том 22 № 92 2020
Науковий вісник Яьвівського національного університету ветеринарної медицини та біотехнологій імені С.3. Гжицького. Серія: Сільськогосподарські науки

Scientific Messenger of Lviv National University of Veterinary Medicine and Biotechnologies. Series: Agricultural sciences

UDC 636.4.082.43

\title{
Signs of reproductive qualities of sows of different types of adaptation, their variability and correlation
}

\author{
V. I. Khalak ${ }^{1}$, B. V. Gutyj ${ }^{2}$ \\ ${ }^{1}$ State Institution Institute of grain crops of NAAS, Dnipro, Ukraine \\ ${ }^{2}$ Stepan Gzhytskyi National University of Veterinary Medicine and Biotechnologies, Lviv, Ukraine
}

\section{Article info}

Received 03.02.2020

Received in revised form 03.03 .2020

Accepted 04.03.2020

State Institution Institute of grain crops of NAAS, V. Vernadsky Str., 14 Dnipro, 49027, Ukraine. Tel.: +38-067-892-44-04 E-mail:v16kh91@gmail.com

Stepan Gzhytskyi National University of Veterinary Medicine and Biotechnologies Lviv,

Pekarska Str., 50, Lviv,

79010, Ukraine.
Khalak V. I., \& Gutyj B. V. (2020). Signs of reproductive qualities of sows of different types of adaptation, their variability and correlation. Scientific Messenger of Lviv National University of Veterinary Medicine and Biotechnologies. Series: Agricultural sciences, 22(92), 35-41. doi: $10.32718 /$ nvlvet-a9207

The results of studies of life expectancy and breeding use, as well as the main indicators of reproductive qualities of sows of large white breed of different types of adaptation, the economic efficiency of the research results and the level of correlation between traits are calculated cost-effectiveness of research results and the level of correlation between traits. The research was conducted in the conditions of agro-formations of Dnipropetrovsk region (LTD "Agro-Elita", SLTD "Druzhba-Kaznacheevka"). The object of the study was sows of large white breed. Evaluation of sows of experimental groups (I-superadaptive, II - mediumadaptive, III - minusadaptive type of adaptation) according to the indicators of the level of adaptation and the main indicators of reproductive qualities were carried out taking into account the successor of quantitative traits: life expectancy, months, duration of breeding use, months, farrowing received, piglets total, head; live pigs obtained, naked; multiplicity, head; weight of the nest at the time of weaning at the age of 28-35 days, kg; duration of intergrowth, days. The adaptation level index and the coefficient of productivity were calculated according to the method of Smirnov V. S. (2003) and Long T. E., Short T. H., Bates $R$. $O$ (2003) respectively. The economic efficiency of the research results was calculated by according to the indicator "mass of the nest at the time of weaning at the age of 28-35 days, $\mathrm{kg}$ ". Analysis of the research results shows that sows of superadaptive type will outperform peers of the opposite class (minusadaptive type) in terms of adaptation level and reproductive capacity by 58.36 and $43.63 \%$ respectively. The proportion of indicator "duration of breeding use, months" to the indicator "life expectancy, months" in animals of superadaptive type is $81.8 \pm 0.76 \%$, minusadaptive $-54.1 \pm 2.67 \%$ (lim $=27.7 \% ; t d=10.00 ; P<0.001)$. An integrated assessment of sow reproductive performance by the performance factor confirms the superiority of sows of the superadaptive type to this group of animal traits of other adaptation types. The paired correlation coefficients between adaptation level indices and reproductive traits in sows of different types of adaptation range from -0.815 ( $t r=6.45$; adaptation level index $\times$ obtained farrowing) to +0.995 ( $t r=45.05$; life expectancy $\times$ duration of tribal use). In order to accelerate the breeding process and create a high-yielding herd of pigs, we suggest that the leading group of sows select animals with an index of "adaptation level" of 6.55-8.90 points.

Key words: sow, life expectancy, breeding duration, reproductive capacity, adaptation type, index, productivity factor, variability, correlation.

\section{Ознаки відтворювальних якостей свиноматок різних типів адаптації, їх мінливість та кореляційний зв'язок}

\author{
В. І. Халак ${ }^{1}$, Б. В. Гутий ${ }^{2}$ \\ 'Державна установа “Інститут зернових культур НААН Украӥни”, м. Дніпро, Украӥна \\ ${ }^{2}$ Львівський національний університет ветеринарної медицини та біотехнологій імені С. 3. Гжицького, \\ м. Львів, Україна
}


Наведено результати досліджень тривалості життя і племінного використання, а також основних показників відтворювальних якостей свиноматок великої білої породи різних типів адаптації, розраховано економічну ефективність результатів досліджень та рівень кореляційних зв'язків між ознаками. Дослідження проведено в умовах агроформувань Дніпропетровської області (ТОВ “Агро-Еліта”, СТОВ “Дружба-Казначеївка”). Об 'єктом дослідження були свиноматки великої білої породи. Оцінку свиноматок піддослідних груп (I - суперадаптивний, II - середньоадаптивний, III - мінусадаптивний тип адаптації) за показниками рівня адаптаиї та основними показниками відтворювальних якостей проводили з урахуванням таких кількісних ознак: тривалість життя, міс., тривалість племінного використання, міс., одержано опоросів, одержано поросят всього, гол.; одержано живих поросят, гол.; багатоплідність, гол.; маса гнізда на час відлучення у віці 28 діб, кг; тривалість міжопоросного періоду, днів. Індекс “рівень адаптаціï” та коефіиієнт продуктивності розраховували за методикою Смірнова B. C. (2003) та Long T. E., Short T. H., Bates R. O (2003) відповідно. Економічну ефективність результатів досліджень розраховували за показником “маса гнізда на час відлучення у вічі 28 діб, кг”. Аналіз результатів досліджень свідчить, шуо свиноматки суперадаптивного типу переважать ровесниць протилежного класу (мінусадаптивного типу) за показниками рівня адаптації та ознаками відтворювальної здатності на 58,36 і 43,63\% відповідно. Частка показника “тривалість племінного використання, міс.” до показника “тривалість життя, міс" у тварин суперадаптивного типу становить 81,8 \pm 0,76 \%, мінусадаптивного - 54,1 \pm 2,67 \% (lim = 27,7 \%; td = 10,00; P < 0,001). Інтегрована оцінка ознак відтворювальної здатності свиноматок за коефіцієнтом продуктивності підтверджує факт переваги свиноматок суперадаптивного типу за даною групою ознак тварин інших типів адаптації. Коефіцієнти парної кореляиї між показниками рівня адаптації та ознаками відтворювальної здатності у свиноматок різних типів адаптації коливаються у межах від -0,815 (tr = 6,45; індекс “рівень адаптацї” × одержано опоросів) до +0,995 (tr = 45,05; тривалість життя $\times$ тривалість племінного використання). 3 метою прискорення селекційного процесу та створення високопродуктивного стада свиней пропонуємо до провідної групи свиноматок відбирати тварин з індексом “рівень адаптацї” 6,55-8,90 бала.

Ключові слова: свиноматка, тривалість життя, тривалість племінного використання, відтворювальна здатність, тип адаптації, індекс, коефіцієнт продуктивності, мінливість, кореляція.

\section{Вступ}

Збільшення виробництва продукції свинарства передбачає виконання певних заходів, а саме: створення оптимальних умов утримання та годівлі, впровадження інноваційних методів оцінки племінної цінності тварин різних статевовікових груп та інше (Goncharuk, 2016; Zhukova et al., 2017; Kramarenko et al., 2018; Karunskiy \& Nikolenko, 2019; Martyshuk et al., 2019).

У зв'язку з інтенсифікацією селекційного процесу, який відбувається з використанням тварин зарубіжного походження, важливим питанням є дослідження рівня їхньої адаптації та реалізація генетичного потенціалу за основними кількісними ознаками в нових екологічних умовах (Bazhov \& Komlatsky, 1989; Bazhov \& Bahyreva 1989; Kovalenko, 2012; Loban, 2014; Khalak et al., 2019; Kozyr et al., 2019; Khalak et al., 2020). Про актуальність зазначеного та проведення подальших досліджень свідчать наукові розробки вітчизняних та зарубіжних вчених (Lugovy, 2005; Tserenyuk et al., 2010; Kislinskaya et al., 2012; Kislinskaya, 2013; Nechmilov, 2018).

Мета роботи - дослідити тривалість життя і племінного використання, а також основні показники відтворювальних якостей свиноматок великої білої породи різних типів адаптації, розрахувати економічну ефективність результатів досліджень та рівень кореляційних зв'язків між ознаками.

\section{Матеріал і методи досліджень}

Дослідження проведено в умовах агроформувань Дніпропетровської області (ТОВ “Агро-Еліта”, СТОВ “Дружба-Казначеївка") та лабораторії тваринництва Державної установи Інститут зернових культур НААН. Робота виконана згідно з ПНД НААН № 30 “Свинарство".

Об'єктом дослідження були свиноматки великої білої породи. Для аналізу характеру успадкування ознак відтворювальної якостей свиноматок різних типів адаптації використовували дані первинної зоо- технічної документації (форма 2-СВ “Картка племінної свиноматки” та 5-СВ “Журнал обліку опоросів свиноматок та приплоду поросят”), а також результати власних досліджень.

Оцінку свиноматок великої білої породи піддослідних груп за ознаками рівня адаптації та відтворювальної здатності проводили з урахуванням таких абсолютних та інтегрованих показників: тривалість життя, міс.; тривалість племінного використання, міс.; індекс “рівень адаптації, балів”, одержано опоросів, одержано поросят всього за період експлуатації матки у стаді, гол.; одержано живих поросят, гол.; багатоплідність, гол.; маса гнізда на час відлучення у віці 28 діб, кг; тривалість міжопоросного періоду, днів.

Індекс “рівень адаптації” (1) та коефіцієнт продуктивності (2) розраховували за формулами:

$$
P A=\frac{T \aleph^{2}}{\text { кількість опоросів } \times \text { ТПВ (міс) }},
$$

де: РА - індекс “рівень адаптаціі”; балів; ТЖ тривалість життя свиноматки (від народження до останнього відлучення поросят), міс.; ТПВ - тривалість племінного використання (від початку першої поросності до останнього відлучення поросят), міс. (Smirnov, 2003);

$$
K \Pi=\frac{X}{\bar{X}} \times 100,
$$

де: КП - коефіцієнт продуктивності, бали; X - індивідуальне значення ознаки, $\overline{\mathrm{X}}$ - середнє значення ознаки по групі тварин (Long et al., 2003).

Формування груп проводили за методикою В. С. Смірнова (2003): I група - суперадаптивний тип, III - мінусадаптивний тип, II - середньоадаптивний тип.

Економічну ефективність проведених досліджень розраховували за формулою:

$$
E=Ц \times \frac{C \times \Pi}{100} \times Л \times K
$$

де: Е - вартість додаткової продукції, грн; Ц - закупівельна ціна одиниці продукції, відповідно до цін, 
які діють в Україні, грн; С - середня продуктивність тварин; П - середня надбавка основної продукції (\%), яка виражена у відсотках на 1 голову при застосуванні нового і поліпшеного селекційного досягнення порівняно 3 продуктивністю тварин базового використання; Л - постійний коефіцієнт зменшення результату, який пов'язаний з додатковими витратами на прибуткову продукцію $(0,75)$; К - чисельність поголів'я сільськогосподарських тварин нового або поліпшеного селекційного досягнення, голів. Економічну ефективність результатів досліджень розраховували за показником "маса гнізда на час відлучення у віці 28 діб, КГ".

Біометричну обробку одержаних результатів досліджень проведено за методикою (Lakin, 1990).

\section{Результати та їх обговорення}

Встановлено, що тривалість життя свиноматок основного стада $(\mathrm{n}=60)$ дорівнює 44,1 $\pm 1,97$ міс. $(\mathrm{Cv}=35,27 \%)$, тривалість племінного використання $32,8 \pm 1,95$ міс. $(\mathrm{Cv}=46,91 \%)$, індекс адаптації $11,87 \pm 0,709(\mathrm{Cv}=47,02 \%)$. Співвідношення показників “тривалість племінного використання свинома- тки, міс.” до “тривалість життя свиноматки, міс.” становить 71,3 \pm 1,53\%. За період племінного використання від свиноматок великої білої породи одержано $6,1 \pm 0,36$ опоросів $(\mathrm{Cv}=47,11 \%)$, поросят усього в розрахунку на одну тварину зазначеної виробничої групи $-65,8 \pm 4,41$ гол. $(\mathrm{Cv}=52,80 \%)$, живих поросят $-62,6 \pm 4,17$ гол. $(\mathrm{Cv}=52,55 \%)$. Багатоплідність свиноматок становить $10,1 \pm 0,20$ гол. $(\mathrm{Cv}=16,02 \%)$; маса гнізда на час відлучення у віці 28 діб - 77,0 $\pm 1,02$ кг $(\mathrm{Cv}=10,45 \%)$, тривалість міжопоросного періоду - $175,3 \pm 3,97$ днів $(\mathrm{Cv}=17,86 \%)$.

Кількість свиноматок класу “еліта" за ознаками “багатоплідність” та "маса гнізда на час відлучення у віці 28 діб, кг” гол.” становить 26,67, I класу - 51,66, II класу - 11,67 \%, позакласні - 10,00 \%.

Дослідження показали, що тварини I групи переважали ровесниць III за показниками “тривалість племінного використання, міс.” на 25,7 міс. (td = 6,94; $\mathrm{P}<0,001)$, “тривалість племінного використання, міс." - на 29,1 міс. (td = 9,73; P < 0,001), індекс “рівень адаптації, балів" - на 13,23 бала $(\mathrm{td}=6,30 ; \mathrm{P}<0,001)$ (табл. 1).

\section{Таблиця 1}

Показники рівня адаптації та ознак відтворювальної здатності свиноматок піддослідних груп

\begin{tabular}{|c|c|c|c|c|}
\hline \multirow{4}{*}{ Показники, одиниці виміру } & \multirow{4}{*}{$\begin{array}{c}\text { Біометричні } \\
\text { показники }\end{array}$} & \multicolumn{3}{|c|}{ Група } \\
\hline & & $\mathrm{I}$ & II & III \\
\hline & & \multicolumn{3}{|c|}{ тип адаптації } \\
\hline & & $\begin{array}{c}\text { супер- } \\
\text { адаптивний }\end{array}$ & $\begin{array}{c}\text { середньо- } \\
\text { адаптивний }\end{array}$ & $\begin{array}{c}\text { мінус- } \\
\text { адаптивний }\end{array}$ \\
\hline \multirow{3}{*}{ Тривалість життя, міс. } & $\mathrm{n}$ & 23 & 26 & 11 \\
\hline & $\overline{\mathrm{X}} \pm S \bar{x}$ & $54,4 \pm 2,16^{* * *}$ & $41,9 \pm 3,09$ & $28,7 \pm 3,00$ \\
\hline & $\mathrm{Cv} \pm \mathrm{Sc}_{\mathrm{v}}, \%$ & $19,09 \pm 2,815$ & $37,54 \pm 5,206$ & $34,73 \pm 7,405$ \\
\hline \multirow{2}{*}{$\begin{array}{l}\text { Тривалість племінного викорис- } \\
\text { тання, міс. }\end{array}$} & $\overline{\mathrm{X}} \pm S \bar{x}$ & $44,8 \pm 2,11^{* * *}$ & $29,6 \pm 2,73$ & $15,7 \pm 2,12$ \\
\hline & $\mathrm{Cv} \pm \mathrm{Sc}_{\mathrm{v}}, \%$ & $22,68 \pm 3,345$ & $47,02 \pm 6,521$ & $44,60 \pm 9,509$ \\
\hline Співвідношення ТЖ: ТПВ, \% & $\overline{\mathrm{X}} \pm S \bar{x}$ & $81,8 \pm 0,76$ & $69,2 \pm 1,45$ & $54,1 \pm 2,67$ \\
\hline \multirow{2}{*}{ Індекс “рівень адаптації”, балів } & $\overline{\mathrm{X}} \pm S \bar{x}$ & $7,80 \pm 0,162 * * *$ & $11,7 \pm 0,38$ & $21,03 \pm 2,099$ \\
\hline & $\mathrm{Cv} \pm \mathrm{Sc}_{\mathrm{v}}, \%$ & $9,95 \pm 1,467$ & $16,69 \pm 2,314$ & $33,40 \pm 7,121$ \\
\hline \multirow{2}{*}{ Одержано опоросів } & $\overline{\mathrm{X}} \pm S \bar{x}$ & $8,6 \pm 0,39 * * *$ & $5,3 \pm 0,42$ & $2,7 \pm 0,35$ \\
\hline & $\mathrm{Cv} \pm \mathrm{Sc}_{\mathrm{v}}, \%$ & $22,08 \pm 3,256$ & $40,96 \pm 5,680$ & $43,67 \pm 9,311$ \\
\hline \multirow{2}{*}{ Одержано поросят усього, гол. } & $\overline{\mathrm{X}} \pm S \bar{x}$ & $96,4 \pm 5,12 * * *$ & $56,3 \pm 5,13$ & $26,4 \pm 4,46$ \\
\hline & $\mathrm{Cv} \pm \mathrm{Sc}_{\mathrm{v}}, \%$ & $25,51 \pm 3,762$ & $46,46 \pm 6,443$ & $55,92 \pm 11,923$ \\
\hline \multirow{2}{*}{ Одержано живих поросят, гол. } & $\overline{\mathrm{X}} \pm S \bar{x}$ & $91,5 \pm 4,69^{* * *}$ & $53,8 \pm 4,82$ & $24,2 \pm 4,34$ \\
\hline & $\mathrm{Cv} \pm \mathrm{Sc}_{\mathrm{v}}, \%$ & $24,61 \pm 3,629$ & $45,63 \pm 6,328$ & $59,33 \pm 12,65$ \\
\hline \multirow{2}{*}{ Багатоплідність, гол. } & $\overline{\mathrm{X}} \pm S \bar{x}$ & $10,6 \pm 0,21^{*}$ & $9,9 \pm 0,20$ & $8,6 \pm 0,82$ \\
\hline & $\mathrm{Cv} \pm \mathrm{Sc}_{\mathrm{v}}, \%$ & $9,93 \pm 1,464$ & $0,33 \pm 0,045$ & $31,75 \pm 6,769$ \\
\hline \multirow{2}{*}{$\begin{array}{l}\text { Маса гнізда на час відлучення у } \\
\text { віці } 28 \text { діб, кг }\end{array}$} & $\overline{\mathrm{X}} \pm S \bar{x}$ & $81,2 \pm 1,51^{* *}$ & $77,2 \pm 1,89$ & $76,4 \pm 1,62$ \\
\hline & $\mathrm{Cv} \pm \mathrm{Sc}_{\mathrm{v}}, \%$ & $9,41 \pm 1,387$ & $12,50 \pm 1,733$ & $8,35 \pm 1,780$ \\
\hline \multirow{2}{*}{$\begin{array}{l}\text { Тривалість міжопоросного пері- } \\
\text { оду, днів }\end{array}$} & $\overline{\mathrm{X}} \pm S \bar{x}$ & $161,1 \pm 2,28 * * *$ & $173,7 \pm 4,41$ & $207,3 \pm 16,08$ \\
\hline & $\mathrm{Cv} \pm \mathrm{Sc}_{\mathrm{v}}, \%$ & $6,79 \pm 1,001$ & $12,96 \pm 1,797$ & $25,73 \pm 5,486$ \\
\hline
\end{tabular}

Примітка: ***-P $<0,001, * *-\mathrm{P}<0,01 ; *-\mathrm{P}<0,05$

Вірогідну різницю між групами тварин протилежних типів адаптації (I - III) встановлено за кількістю одержаних опоросів $(\mathrm{lim}=5,9 ; \mathrm{td}=11,34 ; \mathrm{P}<0,001)$, поросят усього (lim $=70$ гол.; $\mathrm{td}=10,32 ; \mathrm{P}<0,001)$, живих поросят $(\lim =67,3$ гол.; $\mathrm{td}=10,54 ; \mathrm{P}<0,001)$, багатоплідністю ( $\lim =2,0$ гол.; $\mathrm{td}=2,38 ; \mathrm{P}<0,05)$, масою гнізда на час відлучення у віці 28-35 діб $(\lim =4,8$ кг; td $=2,17 ; \mathrm{P}<0,05)$ та тривалістю міжопоросного періоду $(\lim =46,2$ діб; $\mathrm{td}=2,84$; $\mathrm{P}<0,01)$. Максимальну кількість свиноматок класу “еліта" $(54,54$ \%) за ознаками “багатоплідність та “маса гнізда на час відлучення у віці 28-35 діб, кг” гол.” виявлено у групі свиноматок мінусадаптивного типу, I класу $(65,38 \%)$ - у групі свиноматок середньоадаптивного 
типу, II класу (13,04 \%) - у групі свиноматок суперадаптивного типу. Кількість свиноматок класу “позакласні” коливалася в межах від 4,34 (I група) до $18,32 \%$ (III група).

\section{Таблиця 2}

Коефіцієнт продуктивності свиноматок великої білої породи різних типів адаптації

\begin{tabular}{|c|c|c|c|c|}
\hline \multirow{4}{*}{ Показники, одиниці виміру } & \multirow{4}{*}{$\begin{array}{c}\text { Біометричні } \\
\text { показники }\end{array}$} & \multicolumn{3}{|c|}{ Група } \\
\hline & & $\mathrm{I}$ & II & III \\
\hline & & \multicolumn{3}{|c|}{ тип адаптації } \\
\hline & & $\begin{array}{c}\text { супер- } \\
\text { адаптивний }\end{array}$ & $\begin{array}{c}\text { середньо- } \\
\text { адаптивний }\end{array}$ & $\begin{array}{c}\text { мінус- } \\
\text { адаптивний }\end{array}$ \\
\hline \multirow{3}{*}{ Одержано опоросів } & $\mathrm{n}$ & 23 & 26 & 11 \\
\hline & $\overline{\mathrm{X}} \pm S \bar{x}$ & $139,80 \pm 6,560 * * *$ & $87,93 \pm 7,063$ & $44,86 \pm 5,905$ \\
\hline & $\mathrm{Cv} \pm \mathrm{Sc}_{\mathrm{v}}, \%$ & $22,01 \pm 3,246$ & $40,96 \pm 5,680$ & $43,67 \pm 9,311$ \\
\hline \multirow{2}{*}{ Одержано поросят усього, гол. } & $\overline{\mathrm{X}} \pm S \bar{x}$ & $146,40 \pm 7,786 * * *$ & $85,54 \pm 7,793$ & $40,16 \pm 6,771$ \\
\hline & $\mathrm{Cv} \pm \mathrm{Sc}_{\mathrm{v}}, \%$ & $25,51 \pm 3,762$ & $46,46 \pm 6,443$ & $55,92 \pm 11,923$ \\
\hline \multirow{2}{*}{ Одержано живих поросят, гол. } & $\overline{\mathrm{X}} \pm S \bar{x}$ & $146,31 \pm 7,507 * * *$ & $86,04 \pm 7,704$ & $38,78 \pm 6,931$ \\
\hline & $\mathrm{Cv} \pm \mathrm{Sc}_{\mathrm{v}}, \%$ & $24,60 \pm 3,628$ & $45,65 \pm 6,331$ & $59,33 \pm 12,65$ \\
\hline \multirow{2}{*}{ Багатоплідність, гол. } & $\overline{\mathrm{X}} \pm S \bar{x}$ & $105,65 \pm 2,188^{*}$ & $99,59 \pm 2,017$ & $86,00 \pm 8,231$ \\
\hline & $\mathrm{Cv} \pm \mathrm{Sc}_{\mathrm{v}}, \%$ & $9,93 \pm 1,464$ & $10,33 \pm 1,432$ & $31,75 \pm 6,769$ \\
\hline \multirow{2}{*}{$\begin{array}{l}\text { Маса гнізда на час відлучення } \\
\text { у віці } 28 \text { діб, кг }\end{array}$} & $\overline{\mathrm{X}} \pm S \bar{x}$ & $100,25 \pm 1,967$ & $100,22 \pm 2,457$ & $99,14 \pm 2,496$ \\
\hline & $\mathrm{Cv} \pm \mathrm{Sc}_{\mathrm{v}}, \%$ & $9,41 \pm 1,387$ & $12,50 \pm 1,733$ & $8,35 \pm 1,780$ \\
\hline
\end{tabular}

Так, різниця між групами суперадаптивного та мінусадаптивного типів за ознакою “одержано опоросів” становить 94,94 (td = 10,76; P < 0,001), “одержано поросят усього, гол." - 106,24 (td = 10,30; $\mathrm{P}<0,001)$, “одержано живих поросят, гол.” - 107,53 $(\mathrm{td}=10,53 ; \mathrm{P}<0,001)$, “багатоплідність, гол." - 19,65 $(\mathrm{td}=2,30 ; \mathrm{P}<0,05)$, “маса гнізда на час відлучення у віці 28 діб, кг” - 1,11 бала $(\mathrm{td}=0,35 ; \mathrm{P}>0,05)$.

Коефіцієнт парної кореляції є важливим біометричним показником і широко використовується в зоотехнічній практиці для визначення напрямку селекційно-племінної роботи.

За результатами наших досліджень достовірні коефіцієнти парної кореляції у тварин різних типів ада-
Розрахунки коефіцієнта продуктивності свиноматок за основними ознаками відтворювальної здатності підтверджують встановлену закономірність (табл. 2).

\section{Таблиця 3}

Коефіцієнт кореляції між показниками рівня адаптації та ознаками відтворювальних якостей свиноматок піддослідних груп

\begin{tabular}{|c|c|c|c|c|}
\hline \multirow{5}{*}{ Ознаки } & \multirow{5}{*}{$\begin{array}{c}\text { Біометри- } \\
\text { чні показ- } \\
\text { ники }\end{array}$} & \multicolumn{3}{|c|}{ Група } \\
\hline & & $\mathrm{I}$ & II & III \\
\hline & & \multicolumn{3}{|c|}{ тип адаптації } \\
\hline & & супер- & середньо- & мінус- \\
\hline & & адаптивний & адаптивний & адаптивний \\
\hline \multirow{3}{*}{$1-2$} & $\mathrm{n}$ & 23 & 26 & 11 \\
\hline & $\mathrm{r} \pm \mathrm{Sr}$ & $0,995 \pm 0,0218 * * *$ & $0,972 \pm 0,048 * * *$ & $0,938 \pm 0,1155^{* * *}$ \\
\hline & $\operatorname{tr}$ & 45,65 & 20,26 & 8,12 \\
\hline \multirow{2}{*}{$1-3$} & $\mathrm{r} \pm \mathrm{Sr}$ & $-0,618 \pm 0,1716^{* *}$ & $-0,463 \pm 0,1809^{*}$ & $-0,275 \pm 0,3205$ \\
\hline & $\operatorname{tr}$ & 3,60 & 2,56 & 0,86 \\
\hline \multirow{2}{*}{$1-4$} & $\mathrm{r} \pm \mathrm{Sr}$ & $0,953 \pm 0,0661 * * *$ & $0,975 \pm 0,0459 * * *$ & $0,968 \pm 0,0837 * * *$ \\
\hline & $\operatorname{tr}$ & 14,41 & 21,50 & 11,57 \\
\hline \multirow{2}{*}{$1-5$} & $\mathrm{r} \pm \mathrm{Sr}$ & $0,920 \pm 0,0855 * * *$ & $0,965 \pm 0,0535 * * *$ & $0,893 \pm 0,1500 * * *$ \\
\hline & $\operatorname{tr}$ & 10,76 & 18,03 & 5,95 \\
\hline \multirow{2}{*}{$1-6$} & $\mathrm{r} \pm \mathrm{Sr}$ & $0,925 \pm 0,0829 * * *$ & $0,968 \pm 0,0512 * * *$ & $0,928 \pm 0,1242 * * *$ \\
\hline & $\operatorname{tr}$ & 11,16 & 18,90 & 7,47 \\
\hline \multirow{2}{*}{$1-7$} & $\mathrm{r} \pm \mathrm{Sr}$ & $0,217 \pm 0,2130$ & $0,338 \pm 0,1920$ & $0,319 \pm 0,3159$ \\
\hline & $\operatorname{tr}$ & 1,02 & 1,76 & 1,61 \\
\hline
\end{tabular}


Продовж. табл. 3

\begin{tabular}{|c|c|c|c|c|}
\hline \multirow{4}{*}{ Ознаки } & \multirow{4}{*}{$\begin{array}{c}\text { Біометри- } \\
\text { чні показ- } \\
\text { ники }\end{array}$} & \multicolumn{3}{|c|}{ Група } \\
\hline & & $\mathrm{I}$ & II & III \\
\hline & & \multicolumn{3}{|c|}{ тип адаптації } \\
\hline & & $\begin{array}{c}\text { супер- } \\
\text { адаптивний }\end{array}$ & $\begin{array}{c}\text { середньо- } \\
\text { адаптивний }\end{array}$ & $\begin{array}{c}\text { мінус- } \\
\text { адаптивний }\end{array}$ \\
\hline \multirow{2}{*}{$1-8$} & $\mathrm{r} \pm \mathrm{Sr}$ & $-0,016 \pm 0,2182$ & $0,126 \pm 0,2025$ & $0,390 \pm 0,3069$ \\
\hline & $\operatorname{tr}$ & 0,070 & 0,62 & 1,27 \\
\hline \multirow{2}{*}{$1-9$} & $\mathrm{r} \pm \mathrm{Sr}$ & $-0,051 \pm 0,2179$ & $0,251 \pm 0,1976$ & $-0,312 \pm 0,3167$ \\
\hline & $\operatorname{tr}$ & 0,23 & 1,27 & 0,99 \\
\hline \multirow{2}{*}{$2-3$} & $\mathrm{r} \pm \mathrm{Sr}$ & $-0,651 \pm 0,1656^{* *}$ & $-0,576 \pm 0,1669^{* *}$ & $-0,538 \pm 0,2810$ \\
\hline & $\operatorname{tr}$ & 3,93 & 3,45 & 1,91 \\
\hline \multirow{2}{*}{$2-4$} & $\mathrm{r} \pm \mathrm{Sr}$ & $0,956 \pm 0,0640 * * *$ & $0,948 \pm 0,065^{* * *}$ & $0,938 \pm 0,1155^{* * *}$ \\
\hline & $\operatorname{tr}$ & 14,93 & 14,59 & 8,12 \\
\hline \multirow{2}{*}{$2-5$} & $\mathrm{r} \pm \mathrm{Sr}$ & $0,916 \pm 0,0875^{* * *}$ & $0,939 \pm 0,0702 * * *$ & $0,813 \pm 0,1941 * * *$ \\
\hline & $\operatorname{tr}$ & 10,46 & 13,38 & 4,19 \\
\hline \multirow{2}{*}{$2-6$} & $\mathrm{r} \pm \mathrm{Sr}$ & $0,922 \pm 0,0845 * * *$ & $0,939 \pm 0,0702 * * *$ & $0,843 \pm 0,1793 * * *$ \\
\hline & $\operatorname{tr}$ & 10,91 & 13,38 & 4,70 \\
\hline \multirow{2}{*}{$2-7$} & $\mathrm{r} \pm \mathrm{Sr}$ & $0,195 \pm 0,2140$ & $0,315 \pm 0,1937$ & $0,140 \pm 0,3301$ \\
\hline & $\operatorname{tr}$ & 0,91 & 1,63 & 0,42 \\
\hline \multirow{2}{*}{$2-8$} & $\mathrm{r} \pm \mathrm{Sr}$ & $-0,031 \pm 0,2181$ & $0,099 \pm 0,2031$ & $0,345 \pm 0,3129$ \\
\hline & $\operatorname{tr}$ & 0,14 & 0,49 & 1,10 \\
\hline \multirow{2}{*}{$2-9$} & $\mathrm{r} \pm \mathrm{Sr}$ & $-0,051 \pm 0,2179$ & $0,389 \pm 0,1880^{*}$ & $-0,041 \pm 0,3330$ \\
\hline & $\operatorname{tr}$ & 0,23 & 2,07 & 0,13 \\
\hline \multirow{2}{*}{$3-4$} & $\mathrm{r} \pm \mathrm{Sr}$ & $-0,815 \pm 0,1264 * * *$ & $-0,600 \pm 0,1633^{*} *$ & $-0,453 \pm 0,2972$ \\
\hline & $\operatorname{tr}$ & 6,45 & 3,67 & 1,52 \\
\hline \multirow{2}{*}{$3-5$} & $\mathrm{r} \pm \mathrm{Sr}$ & $-0,654 \pm 0,1651 * * *$ & $-0,571 \pm 0,1676^{* *}$ & $-0,271 \pm 0,3209$ \\
\hline & $\operatorname{tr}$ & 3,96 & 3,41 & 0,84 \\
\hline \multirow{2}{*}{$3-6$} & $\mathrm{r} \pm \mathrm{Sr}$ & $-0,674 \pm 0,1612 * * *$ & $-0,562 \pm 0,1688^{* *}$ & $-0,272 \pm 0,3208$ \\
\hline & $\operatorname{tr}$ & 4,18 & 3,33 & 0,85 \\
\hline \multirow{2}{*}{$3-7$} & $\mathrm{r} \pm \mathrm{Sr}$ & $0,151 \pm 0,2157$ & $-0,105 \pm 0,2030$ & $0,252 \pm 0,3226$ \\
\hline & $\operatorname{tr}$ & 0,70 & 0,52 & 0,78 \\
\hline \multirow{2}{*}{$3-8$} & $\mathrm{r} \pm \mathrm{Sr}$ & $0,097 \pm 0,2172$ & $-0,039 \pm 0,2040$ & $-0,131 \pm 0,3305$ \\
\hline & $\operatorname{tr}$ & 0,45 & 0,19 & 0,40 \\
\hline \multirow{2}{*}{$3-9$} & $\mathrm{r} \pm \mathrm{Sr}$ & $0,543 \pm 0,1832 * *$ & $-0,014 \pm 0,2041$ & $-0,310 \pm 0,3169$ \\
\hline & $\operatorname{tr}$ & 2,96 & 0,07 & 0,98 \\
\hline
\end{tabular}

Примітка: 1- тривалість життя, міс.; 2 - тривалість племінного використання, міс.; 3 - індекс “рівень адаптаціі”, балів; 4 одержано опоросів; 5 - одержано поросят усього, гол.; 6 - одержано живих поросят, гол.; 7 - багатоплідність, гол.; 8 - маса гнізда на час відлучення у віці 28 діб, кг; 9 - тривалість міжопоросного періоду, діб

Кількість достовірних зв’язків між показниками рівня адаптації та ознаками відтворювальної якостей у свиноматок піддослідних груп коливалася у межах від 50,0 до $63,6 \%$.

Таблиця 4

Економічна ефективність результатів досліджень

\begin{tabular}{ccccc}
\hline Група & $\mathrm{n}$ & $\begin{array}{c}\text { Маса гнізда на час відлу- } \\
\text { чення у віці 28 діб, кг }\end{array}$ & Надбавка продукції, \% & $\begin{array}{c}\text { Вартість додаткової } \\
\text { продукції, грн./гол.* }\end{array}$ \\
\hline Загальна вибірка & 60 & $77,0 \pm 1,02$ кг & - & - \\
III & 11 & $76,4 \pm 1,62$ & $-0,77$ & $-18,89$ \\
II & 26 & $77,2 \pm 1,89$ & $+0,25$ & $+6,13$ \\
I & 23 & $81,2 \pm 1,51$ & $+5,17$ & $+126,89$ \\
\hline
\end{tabular}

Результати розрахунку економічної ефективність використання свиноматок різних типів адаптації наведено в таблиці 4.

Примітка: ціна реалізації молодняку свиней на час проведення досліджень дорівнювала 42,50 грн/кг

Встановлено, що максимальну надбавку додаткової продукції за показником "маса гнізда на час відлучення у віці 28 діб, кг” (+5,17 \%) одержано від тварин суперадаптивного типу. Ї̈ї вартість становить 126,89 грн.

\section{Висновки}

1. Встановлено, що свиноматки суперадаптивного типу переважать ровесниць протилежного класу (мінусадаптивного типу) за показниками рівня адаптації та ознаками відтворювальної здатності на 58,36 i 43,63 \% відповідно. Частка показника “тривалість племінного використання, міс.” до показника “тривалість життя, міс.” у тварин суперадаптивного типу становить $81,8 \pm 0,76 \%$, мінусадаптивного $54,1 \pm 2,67 \%(\lim =27,7 \% ; \mathrm{td}=10,00 ; \mathrm{P}<0,001)$.

2. Інтегрована оцінка ознак відтворювальної здат- 
ності свиноматок за коефіцієнтом продуктивності підтверджує факт переваги свиноматок суперадаптивного типу за даною групою ознак тварин інших типів адаптації.

3. Коефіцієнти парної кореляції між показниками рівня адаптації та ознаками відтворювальної здатності у свиноматок різних типів адаптації коливаються у межах від $-0,815$ (tr $=6,45$; індекс “рівень адаптації” $\times$ одержано опоросів) до $+0,995$ ( $\operatorname{tr}=45,05$; тривалість життя $\times$ тривалість племінного використання).

4. Максимальну надбавку додаткової продукції за показником "маса гнізда на час відлучення у віці 28 діб, кг” (+5,17 \%) одержано від тварин суперадаптивного типу. Ї̈ї вартість становить 126,89 грн.

5. 3 метою прискорення селекційного процесу та створення високопродуктивного стада свиней пропонуємо в умовах племінних господарств регіону систематично проводити оцінку тварин основного за абсолютними та інтегрованими показниками. До провідної групи свиноматок відбирати тварин з індексом "рівень адаптації” 6,55-8,90 бала.

Подяка. Автори висловлюють офіційну подяку генеральному директору СТОВ “ДружбаКазначеївка” Дніпропетровської області, кандидату с.-г. наук Савельєву В. І., головному технологу Шепель Н. О. та зоотехніку-селекціонеру Бичівник П. А., які сприяли організації та проведенню наукових досліджень.

\section{References}

Bazhov, G. M., \& Bakhireva, L. A. (1989). Natural resistance of pigs of different breeds. Intensification of the selection process in pigbreeding: collection. scientific labor. Persianovka, 37-41 (in Russian).

Bazhov, G. M., \& Komlatsky, V. I. (1989). Biotechnology of intensive pig breeding. M.: Rosagropromizdat (in Russian).

Goncharuk, A. (2016). PVMA "Intermiks" in rations pigs. Scientific Messenger of LNU of Veterinary Medicine and Biotechnologies. Series: Agricultural Sciences, 18(2), 52-56. doi: 10.15421/nvlvet6712.

Halak, V. I., Chernyavsky, S. E., Voloschuk, V. M., Chernyaev, K. F., \& Il'chenko, M. O. (2019). Feeding and meat characteristics of young pigs of different genotypes according to SNP c.1426 G> A of melanocortin 4 (MC4R) receptor gene and their distribution on some grounds. Pigbreeding. Interagency thematic scientific collection of the Institute of Pigbreeding and AIP of NAAS, 73, 157-165 (in Ukrainian).

Karunskiy, A., \& Nikolenko, I. (2019). The effective use of biologically active substance that belongs to hydrolyse class "Lysozyme G3" in the composition of pigs premix. Scientific Messenger of LNU of Veterinary Medicine and Biotechnologies. Series: Agricultural Sciences, 21(90), 93-97. doi: 10.32718/nvlvet-a9016.

Khalak, V., Gutyj, B., Bordun, O., Il'chenko, M., \& Horchanok, A. (2020). Effect of blood serum enzymes on meat qualities of piglet productivity. Ukrainian Journal of Ecology, 10(1), 158-161. doi: 10.15421/2020_25 (in Ukrainian).
Khalak, V.I., Gutyj, B.V., \& Stadnits'ka, O.I. (2019). Feeding and meat qualities of young pigs of different origin and intensity of formation in early ontogenesis. Scientific Messenger of Lviv National University of Veterinary Medicine and Biotechnologies. Series: Agricultural sciences, 21(91), 10-15. doi: 10.32718/nvlvet-a9102.

Kislinskaya, A. I. (2013). Feeding and meat qualities of purebred young pigs of large white breed of the Hungarian selection and their crossbreeds in the postadaptation period. Krasnodar: Krasnodar State Agrarian University, 6, 167-171 (in Russian).

Kislinskaya, A. I., Kalinichenko, G. I., Shakun, A. P., \& Tyshko, N. I. (2012). Assessment of the natural resistance of the organism of large white pigs of the Hungarian selection during adaptation. Modern trends and technological innovations in pig breeding: materials of the 19th International Scientific and Practical Conf.; Slides: BSAA, 78-83 (in Russian).

Kovalenko, N. A. (2012). Dynamics of biochemical parameters of blood of young pigs of large white breed of Austrian breeding during adaptation. Veterinary pathology, 2, 72-75 (in Russian).

Kozyr, V., Khalak, V., \& Povod, M. (2019). DNA-type results swine for MS4R-gene and its association with productivity. Agrolife: Scientific journal. University of Agronomic Sciences and Veterinari Medicine of Bucharest, 8(1), 128-133.

Kramarenko, S., Lugovoy, S., Lykhach, A., Kramarenko, A., \& Lykhach, V. (2018). A comparative study of the reproductive traits and clustering analysis among different pig breeds. Scientific Messenger of LNU of Veterinary Medicine and Biotechnologies. Series: Agricultural Sciences, 20(84), 21-26. doi: $10.15421 /$ nvlvet8404.

Lakin, H. F. (1990). Biometriia: schoolbook for biol. specialty University. Moskow, Vysshaia shkola (in Russian).

Loban, N. A. (2014). A system of breeding and genetic methods for assessing the fattening and meat quality of pigs. Pigbreeding. Interagency thematic scientific collection of the Institute of Pigbreeding and AIP of NAAS, 65, 69-75 (in Russian).

Long, T. E., Short, T. H., \& Bates, R. O. (2003). Estimating genetic merit / NSIF Swine Genetics. Fact Sheets, $8,1-4$.

Lugovy, S. I. (2005). Reproductive ability of sows of a large white breed of English breeding. Agrarian Bulletin of the Black Sea, 31, 44-45 (in Ukrainian).

Martyshuk, T. V., Gutyj, B. V., Vishchur, O. I., \& Todoriuk, V. B. (2019). Biochemical indices of piglets blood under the action of feed additive "Butaselmevitplus". Ukrainian Journal of Veterinary and Agricultural Sciences, 2(2), 27-30. doi: 10.32718/ujvas2-2.06.

Nechmilov, V.M. (2018). The influence of the factor of the method of hybrid pigs feeding while growing on the meat quality. Scientific Messenger of Lviv National University of Veterinary Medicine and Biotechnologies, 20(89), 56-60. doi: 10.32718/nvlvet8910 (in Ukrainian).

Neumann, D. (1987). Neue Handelsklassenverordnung fur Schweinehalten. Zandwirschaftliche. Zeitschrift, 157(13), 882-886. 
Smirnov, V. S. (2003). Assessment of adaptation of sows to intensive reproduction. Zootechny, 7, 22-25 (in Russian).

Tserenyuk, O. M., Khvatov, A. I., \& Strizhak, T. A. (2010). Evaluation of the performance of pigs' maternal productivity indices. Collection of scientific works of Vinnitsa NAU, 3(42), 73-77 (in Ukrainian).
Zhukova, I., Molchanov, A., \& Antipin, S. (2017). Increase in resistance of pigs to oxidative stress by means of plant origin. Scientific Messenger of LNU of Veterinary Medicine and Biotechnologies. Series: Agricultural Sciences, 19(74), 33-37. doi: $10.15421 /$ nvlvet7408. 